\title{
The Influence of Teacher Expectation on Students' Achievement of Different Grades
}

\begin{abstract}
Huaxi Sun ${ }^{1, *}$
${ }^{1}$ Syracuse University, Syracuse, New York, United States

*Corresponding author. Email: hsun31@syr.edu

ABSTRACT

Previous studies have found that teacher expectations affect students' academic performance, but whether the effects on different students are the same still needs to be explored. This article will discuss the influence of teacher expectation on students' achievement and whether the impact is different for different grades students. This paper analyzes the different influences of teacher expectation on three-stage students (primary school, middle school, university students). By reviewing recent research, this paper finds the different impacts of teacher expectation. Teacher expectations have higher effects on primary school students than other-age students. Till students move on to college, the effects change but remain. In addition, this paper mentions the cultural differences and individual differences like characters between teachers and students. The influencing mechanism of teacher expectation on students' achievement is also mentioned in this review. Students' motivation can be improved under high expectations, and different students will have a different understanding of teacher expectations. In conclusion, from these analyses, teachers, and educators can better understand the relationship between teacher expectation and students' achievement. Also, the future researcher could have a new perspective on teacher expectations.
\end{abstract}

Keywords: Teacher expectation effect, Students' achievement, Different grades students.

\section{INTRODUCTION}

Teacher expectations are beliefs teachers have about their students' potential achievement [1]. According to the teacher expectation, Rosenthal and Jacobson [2] create an effect called the teacher expectation effect. This effect is important because lots of researchers have justified that it can affect students' achievement. Timmermans et al. [3] said till 2018, this effect has been built for 50 years. In these fifty years, researchers have done lots of different experiments on teacher expectations and got rich research results. Timmermans et al. [3] summarized these studies: To research teacher expectation and the effect on students' achievement of it, different students, teachers, schools, families, and communities need to be considered.

As summarized by Timmermans et al. [3], developmental psychologists considered different factors. They have made relevant discussions on the impact of teacher expectations on different ages students. Students of different ages have different developmental characteristics. Younger students trust teachers almost unconditionally, and their trust in teachers even exceeds their trust in parents [4]. Also, Wang and Wang [4] justify that students' academic performance has a significant predictive effect on the teacher-student relationship. Students with good academic performance have a better teacher-student relationship. For middle school students, they are in puberty, one of the most significant biological and social transitions in a person's life [5]. They will be more fragile in their hearts, and if teachers do something that hurts them, it will greatly impact their performance and future [6]. Compared with these young ages and middle school students, university students are mature and represent higher education. They often have their own ideas and know what they need to do. Many articles talk about how teacher expectations affect students' achievement, which focused on some specific age students like primary school students, middle school students, and university students. But few researchers compare teachers' impact of all ages 
on students together. However, finding the different influences is important because teachers can know how to treat different grades of students. As mentioned above, students at each stage have different psychological characteristics, and teachers need to control their expectations according to students' different psychological characteristics. In this article, the influence of teacher expectation in different grades students will be discussed, and differences between them will be found. This review hopes to provide a new idea for educators who study teachers' expectations and other front-line educators. In future research, people can explore the age trend of the influence of educational expectation from a developmental perspective.

So, to sum up, the research question in this article is: Do teacher expectations have different impacts on different ages students' achievement? To clarify this question, this paper discusses the following aspects: Part one introduces the background, purpose, and structure of the thesis. This part illustrates the importance and specific value of this study. Part two mentioned the history of the Pygmalion effect and how it develops into the teacher expectation effect. The specific processes are also mentioned in this part. Part three is the impact of teacher expectations on different ages, students' achievement, which talked about teacher expectations on primary school, middle school, and university students. Several empirical studies are used to find the different impacts between the three stages. The fourth part is about the individual differences in teacher expectation effect. That is about students' character and teachers' culture. The influencing mechanism is in the fifth part, which discussed two main ways of how teacher expectations affect students' achievement. One of them is teacher expectation can improve students' motivation. And another one is students have a different understanding of teacher expectations. Finally, the sixth part is the conclusion of this article.

\section{TEACHER EXPECTATION EFFECT}

Researchers have been interested in the impact of teacher expectations on student performance since the late 1960s [7]. To talk about the history of teacher expectation, we should know the Pygmalion effect created by Rosenthal and Jacobson [2]. They experimented. First, they conducted an IQ test for all students in a middle school and then told the teacher that some students had a very high IQ. But in fact, these so-called "high IQ" students are not high IQ, but randomly selected. Therefore, their IQ is not higher than the rest of the students. The results of the subsequent experiments were astonishing: the students who were considered "high IQ" by the teacher (the truth is the same as the IQ of the rest of the students) did indeed improve their academic performance in the coming year. So, they concluded that if the teacher expectations of the students are strengthened, the students' performance will be relatively strengthened. In 1980, Good and Brophy [8] conducted a detailed analysis of the Pygmalion effect. They believe that the process of expectation effect is that teachers have different attitudes and expectations towards students. Then students react differently, and their academic performance will increase or decrease along with the teacher's expectation [8].

Later, Braun [9] construct a model of teachers' expectations, that is, the model of teacher's expectation effect. In his article, Braun [9] talked about the reason and process of how the teacher expectation effect was produced. In terms of reasons, Braun [9] proposed factors such as physical characteristics, gender, academic performance, and socioeconomic status. In terms of the process, Braun [9] believes that teachers produce a subjective reflection, and they will respond accordingly in cognition, emotion, and behavior. They will first group the students into good and bad groups and have different expectations of them. There are more questions, more praise, more motivational hints, more difficult questions for students with good grades, and less on the contrary. This attitude and behavior of teachers undoubtedly play a positive role in promoting the top students and produce obvious expectation effects.

After that researcher begins to study the teacher expectation effect from the point of view, some researchers will discuss teacher expectations in a different course. For instance, Smith [10] discovered that teacher expectations had a greater impact on reading achievement than math achievement or the student's I.Q. In researching teacher expectation effect, the most researcher will first collect teacher expectations from teachers. They always asked teachers to do a questionnaire on their thinking and expectation of all their students. Next, the researcher will collect students' final grades and compare them with teachers' expectations. This is the most commonly used method in previous studies, which is directly and accurately. There are articles about teacher expectation effect in different age students separately, but few people compare students of different ages side by side. So, that's the main point this article will focus on in the following article.

\section{THE IMPACT OF TEACHER EXPECTATION ON DIFFERENT AGES STUDENTS' ACHIEVEMENT}

As we all know, students have different stages. But teachers always have their expectations. Will students' age 
make a difference in the relationship between teacher expectation and students' accomplishment?

\subsection{Preschool and primary school students}

In both preschool and primary school, students are first time faced with education by teachers. It's all-new things for them, and they will think less than other years old students. Also, they will unconditionally trust what the teacher says [4]. To find the relationship between teacher's expectations and young age students' achievements, Chen et al. [11] first focused on the relationship between teacher's oral feedback with teacher's expectations. And they found teachers will show less negative feedback to the students they have higher expectations on. After that, they got a result: students who perceived more positive feedback would have higher self-concept and have higher achievement. In another article, Rubie-Davies [12] researched preschool and primary school students and got a similar result. In this research, the author collects teacher's expectations of students and students' spring achievement in October and then compared it with prior year achievement. The results are at all three grade levels, Kindergarten, first grade, and fourth grade. Teacher expectations were found to predict students' year-end achievement independently and significantly. Which means high expectations from teachers lead to high academic achievement. From these two empirical studies, the relationship between teacher expectation and students' achievement can be summarized as: Teacher expectation expects to greatly impact primary school students in most cases.

\subsection{Middle school students}

In this part, middle school students will be focused on which are a little bit mature than primary school students, and they are in puberty. In research, Ketsman [13] designed a questionnaire and interview for two teachers in two high schools, and also used observation to make sure teacher expectation is accurate. Ketsman [13] chose these two teachers because students in their class get higher grades than other class students. From the questionnaire, interview, and observation, Ketsman [13] got why two of them all think "expectations are huge for achievement". In another research done by Ding [14, selects middle school students as the participants. The students were separated into high expectation students, mid expectation students, and low expectation students at first. This study is different from the previous one because teachers were told to intervene with all students. So, Ding [14] can find the differential gains in different groups of students in the intervention. The result is intervention can improve all students' year-end grades. And low-mid expectation students' self-concept is improved. Because the intervention seems to provide low expectation students with opportunities for achievement that they may not have had previously. In conclusion, the teacher shows high expectations to students can affect all students' grades and improve students' self-concept. Middle school students still can influence a lot by teacher expectations, especially those who have never been highly anticipated by their teachers before.

\subsection{University students}

In the last groups of students, university students will be talked since it's represented higher education. They already have their own thinking and know what they need to do. Like the middle school one, Li [15] researched Chinese University and selected 50 students and over 4000 students as the participants. Teachers were asked to anticipate the level each student would reach in the final year standardized examination. And these anticipate grades represent their expectations of students. Also, researchers collect students' grades from The University Entrance Examination. Raudenbush's [16] research revealed that professors build their expectations of students early in the academic year. This means teachers will anticipate students' grades based on their grades from The University Entrance Examination. After they did the expectation scale, they will have a conversation with all students to know about how teachers expect them. One of the things justified in this article is that although they are university students, they still will affect a lot by teacher's expectations when they are in their transitional phase. When students enter a new place, they need validation from other people, especially their teachers $[16,17]$. Niari et al. [18] done a teacher expectation effect experiment in university and got a result which is a positive attitude and expectation from tutors help them a lot. Still, the negative ones can affect their attitude toward learning. Students can feel the encouragement from their teachers, and teachers' expectations most time affect adult students depends on their will, personal work, and determination. That's the difference between college students and students younger than them. To sum up, college students can affect by teacher expectations, but there are some preconditions. The first is when they just study in a university. They are easier affected by teacher expectations. The second one is whether they can impact by teacher expectation is decided by themselves will. 


\section{INDIVIDUAL DIFFERENCES IN TEACHER EXPECTATION EFFECT}

Besides the students' grades can make a difference, there are many other students' and teachers' own character factors.

\subsection{Students' character}

\subsubsection{Self-concept}

Different students will have different reactions to the teacher's expectations. One of the most important issues that can affect students is their self-concept. Have a higher self-concept can have a better effect. Brattesani et al. [19] have done a study in primary school that shows that students' self-concept can mediate the influences of teachers' expectations. Regarding the math research done by Friedrich et al. [20] in primary school, prior academic achievement and ability judgments of significant others can both positively influence students' self-concept. If students have a high self-concept to themselves, they will improve more and get better grades.

\subsubsection{Students' gender}

Compared with male students, female students are easier affected by teachers [21-23]. Girls are more sensitive than boys, which means if they received some sign of a teacher's low expectations, they will feel upset and get lower grades.

\subsection{Teachers' character}

Several different factors will affect teachers' expectations of students, including gender, ethnicity, etc. Also, Gershenson et al. [24] have done an empirical study in high school and said that cultural factors are important in shaping teacher expectations, and research has shown that teachers form beliefs based on previous experiences with attributes. Moreover, for a very small number of teachers, including all ages students' teachers, there can be a bias against some ethnicity which means they will have lower expectations to some ethnic students [25].

\section{INFLUENCING MECHANISM}

From the previous passage, we already know teacher's expectations can affect student's achievement. But how does it make a difference is what we need to have a further explanation. There are two possible influential ways. The first one is what Hornstra [26] mentioned in his article, teacher's expectations can improve students' motivation in the study. To achieve teacher's expectations to themselves, students will spend more time on study and work harder. In addition, People are happy and motivated when they are praised for something. Another one is about students' character and their understanding of the teacher's expectations. Previous research has found that female students may be more vulnerable to teachers' stereotyped expectations in math [21-23]. That will lead to the fact that these students will easily feel pressure from the teacher's expectations. In addition, Wong [27] said that expectations could create worry and concern among some high achieving students. They will be worried about whether they can achieve the expectations their teacher has on them. These pressures can affect students a lot. So, students' character will make their reaction differently under teacher's expectation. To sum up, teacher expectations impact students' achievement in two ways: improving their motivation and students' own understanding of it.

\section{CONCLUSION}

The current study is willing to find the different influences of teacher expectation on students' achievement. Primary school and preschool students can be affected more since they are at a very young age, and in their mind, all teacher's words are correct and need to be followed. For middle school students, they still can affect by teacher expectation, but the impact will be smaller. Last is the university students. They can be impacted when they just go to university because at this stage. They need other people's approval. Also, when they adapt to the university, they will still improve under high expectations, but it will be decided by themselves. The teacher expectation effect will have different influences on different ages students. In addition, teachers' and students' cultural and individual differences can affect a lot too. Moreover, students' motivation can be improved under high expectations, and they can have a different understanding of their teacher's expectations. From this article, teachers and educators can have further thought on treating different age students in teacher expectation areas. Future research can focus on compared different ages students under teacher expectation effect.

\section{REFERENCES}

[1] Rubie-Davies, C. M. (2006). Teacher expectations and student self-perceptions: Exploring relationships. Psychology in the Schools, 43, 537552.

[2] Rosenthal. R. and Jacobson. L. (1968) Pygmalion in the classroom: Teacher expectations and pupils' intellectual development. New York: Holt 
[3] Timmermans, A. C., Rubie-Davies, M. C. \& Rjosk, C. (2018). Pygmalion's 50th anniversary: the state of the art in teacher expectation research. Educational Research and Evaluation, 24(3-5), 91-98.

[4] Wang, Y., Wang, X. (2002) Development of TeacherStudent Relationships and Its relation to Factors in Primary School. Psychology Development and Education, 2002(3):18-23

[5] Susman, E. J., \& Rogol, A. (2004). Puberty and psychological development. In. R. M. Lerner \& L. Steinberg (Eds.), Handbook of adolescent psychology (Vol. 2, pp. 15-44).

[6] Yu, L. (2005). Psychological Problems of Middle School Students in Adolescence and Educational Countermeasures. Journal of Teaching and Management. 2005(9):29-30

[7] Cooper, H. M. (1983). A Historical Overview of Teacher Expectation Effects.

[8] Good. T. and Brophy - J. (1980). Educational psychology: A realistic Approach (2nd ed.). New York: Holt

[9] Braun, C. (1976). Teacher Expectation: Sociopsychological Dynamics. Review of Educational Research, 46(2), 185-213.

[10] Smith. M. Mata-analysis of research on teacher expectations. Evaluations in Education, 1980,4,55355

[11] Chen, Y., Marilyn S. Thompson, Jeffrey D. Kromrey \& George H. Chang (2011) Relations of Student Perceptions of Teacher Oral Feedback with Teacher Expectancies and Student Self-Concept, The Journal of Experimental Education, 79:4, 452-477

[12] Rubie-Davies, C. M., Weinstein, R. S., Huang, F. L., Gregory, A., Cowan, P. A., \& Cowan, C. P. (2014). Successive teacher expectation effects across the early school years. Journal of Applied Developmental Psychology, 35(3), 181-191.

[13] Ketsman, O. (2012). Expectations in the Foreign Language Classrooms: A Case Study. The Qualitative Report, 17(53), 1-21.

[14] Ding, H., \& Rubie-Davies, C. M. (2019). Teacher expectation intervention: Is it effective for all students? Learning and Individual Differences, 74, 101751
[15] Li, Z. (2014). Teachers matter: Expectation effects in foreign language classrooms at university (Doctoral dissertation, ResearchSpace@Auckland).

[16] Raudenbush, S. W. (1984). Magnitude of teacher expectancy effects on pupil IQ as a function of the credibility of expectancy induction: A synthesis of findings from 18 experiments. Journal of Educational psychology, 76(1), 85-97.

[17] Wentzel, Kathryn R. 1997. "Student Motivation in Middle School: The Role of Perceived Pedagogical Caring." Journal of Educational Psychology 89 (3): 411-19

[18] Niari, M., Manousou, E., \& Lionarakis, A. (2016). The Pygmalion effect in distance learning: A case study at the Hellenic Open University. European Journal of Open, Distance and E-learning, 19(1), 36-53.

[19] Brattesani, K. A., Weinstein, R. S., \& Marshall, H. H. (1984). Student perception of differential teacher treatment as moderators of teacher expectation effects. Journal of Educational Psychology, 76, 236247

[20] Friedrich A., \& Flunger B., Nagengast B., Jonkmann K., Trautwein U. (2014). Pygmalion effects in the classroom: Teacher expectancy effects on students' math achievement. Contemporary Educational Psychology 41 (2015) 1-12.

[21] Eccles, J., \& Hoffman, L. W. (1984). Socialization and the maintenance of a sex-segregated labor market. In H. Stevenson \& A. Siegel (Eds.), Research in child development and social policy (Vol. 1, pp. 367-420).

[22] Eccles, J., \& Jacobs, Janis E. (1986). Social forces shape math attitudes and performance. Signs, 11(2), 367-380.

[23] Meece, J. L., Parsons, J. E., Kaczala, C. M., \& Goff, S. B. (1982). Sex differences in math achievement: Toward a model of academic choice. Psychological Bulletin, 91(2), 324.

[24] Gershenson, S., Holt, S. B., \& Papageorge, N. W. (2016). Who believes in me? The effect of studentteacher demographic match on teacher expectations. Economics of Education Review, 52, 209--224.

[25] Flanagan, A.M., Cormier, D.C. \& Bulut, O. Achievement may be rooted in teacher expectations: examining the differential influences of ethnicity, years of teaching, and classroom behavior. Soc Psychol Educ 23, 1429-1448 (2020). 
[26] Hornstra, L., Stroet, K., Eva van Eijden, Goudsblom, J. \& Roskamp, C. (2018). Teacher expectation effects on need-supportive teaching, student motivation, and engagement: a self-determination perspective. Educational Research and Evaluation, 24(3-5), 324345.

[27] Wong, M. (2014). Voices of children, parents, and teachers: How children cope with stress during school transition. Early Childhood Development and Care, $185,1-21$ 